\title{
ANALYSIS OF INFLUENCE OF CUTTING PARAMETERS ON SURFACE ROUGHNESS AND TOOL WEAR IN HARD TURNING SINTERED TUNGSTEN CARBIDE USING CBN INSERTS
}

Nguyen Quoc Tuan, Ngo Minh Tuan*

$T N U$ - University of Technology

\begin{tabular}{r} 
ARTICLE INFO \\
\hline Received: 02/12/2020 \\
Revised: 06/02/2021 \\
Published: $12 / 03 / 2021$ \\
KEYWORDS
\end{tabular}

Hard turning

Tungsten carbide

CBN

Tool wear

Surface roughness

\begin{abstract}
Hard turning is a potential machining process to replace for grinding process due to many advantages such as high material removal rate, good surface integrity, and friendly environment. Sintered tungsten carbide is widely used for the die and molds of the metal forming process because of their high hardness and wear resistance compared with alloy steel. CBN is a super hard cutting tool material used for machining difficult-to-cut materials as tungsten carbide. In this research, the influence of the cutting parameters including cutting speed, feed rate and cutting depth on the flank wear and surface roughness was analyzed by using $2^{\mathrm{k}}$ experimental model with some center points. The results investigated that the feed rate is the most significant parameter effecting on the surface roughness in the machining process and the cutting speed strongly affects on the flank wear in the hard turning of sintered tungsten carbide using CBN inserts. The results of ANOVA analysis for the surface roughness and the flank wear indicated that the curve models were required to describe the effect of the cutting parameters on the surface roughness and the flank wear in this machining process.
\end{abstract}

\section{PHÂN TÍCH ẢNH HỬ̛̉ng CỦA CHẾ ĐỘ CẮT TỚI NHÁM BỀ MẠT VÀ MÒN DỤNG CỤ KHI TIỆN CÚNG CACBUA VONFRAM SỦ̉ DỤNG MẢNH CBN}

Nguyễn Quốc Tuấn, Ngô Minh Tuấn*

Truờng Đại học Kỹ thuật Công nghiệp - ĐH Thái Nguyên

\begin{tabular}{c}
\hline THÔNG TIN BÀI BÁO \\
\hline Ngày nhận bài: 02/12/2020 \\
Ngày hoàn thiện: 06/02/2021 \\
Ngày đăng: 12/03/2021 \\
Từ KHÓA \\
\hline
\end{tabular}

Tiện cứng

Các bít vonfram

CBN

Mòn dụng cụ

Nhám bề mặt

\section{TÓM TẮT}

Tiện cứng là một quá trình gia công có tiềm năng thay thế cho quá trình mài do có nhiều ưu điểm như năng suất cắt cao, bề mặt gia công tốt, thân thiện với môi trường. Cacbua vonfram thiêu kết được sử dụng rộng rãi để làm chày và khuôn cho các quá trình gia công biến dạng dẻo kim loại vì độ cứng cao và khả năng chống mài mòn so với thép hợp kim. $\mathrm{CBN}$ là vật liệu dụng cụ cắt siêu cứng được sử dụng để gia công các vật liệu khó gia công bằng cắt như cacbua vonfram. Trong nghiên cứu này, ảnh hưởng của các thông số cắt bao gồm vận tốc cắt, lượng chạy dao và chiều sâu cắt đến lượng mòn mặt sau và độ nhám bề mặt được phân tích bằng cách sử dụng mô hình thí nghiệm $2^{\mathrm{k}}$ với một số điểm thí nghiệm ở tâm. Kết quả nghiên cứu cho thấy lượng chạy dao là thông số có ý nghĩa nhất ảnh hưởng đến độ nhám bề mặt trong quá trình gia công và vận tốc cắt ảnh hưởng mạnh đến lượng mòn mặt sau của dao trong quá trình tiện cứng cacbua vonfram thiêu kết sử dụng mảnh CBN. Kết quả phân tích ANOVA đối với độ nhám bề mặt và lượng mòn mặt sau cho thấy cần phải sử dụng mô hình đường cong để mô tả ảnh hưởng của các thông số cắt đến độ nhám bề mặt và lượng mòn mặt sau trong quá trình gia công này.

DOI: $\underline{\text { https://doi.org/10.34238/tnu-jst.3814 }}$

\footnotetext{
${ }^{*}$ Corresponding author. Email: minhtuanngo@tnut.edu.vn
} 


\section{Introduction}

The hot forming compression molds are commonly used in the glass lens manufacturing process. Sintered tungsten carbide WC is suitable for these molds because of their good properties such as heat and wear resistance, high hardness and good strength. These properties create difficulty in the machining process. The classical machining methods as EDM, polishing or grinding were used for machining the sintered tungsten carbide. However, these methods have many limitations such as low productivity, difficulty to shape the geometrical flexibility, use of the coolant or electrolyte liquid [1]. Nowadays, hard material machining methods are used to replace the classical machining process as there are more advantages.

Machined surface qualities greatly affect the functional performance of machined parts such as wear resistance, tribological properties and fatigue strength. In the machining process, the surface roughness of machined parts is one of the important behavior in order to evaluate the surface qualities [2]. The diamond turning characteristics of tungsten carbide with a chamfered diamond edge were studied by using the simulated and experimental methods [3]. The results showed that the surface roughness for turning tungsten carbide using the chamfered tool was better than the surface roughness for the turning process using the conventional tool. The research of Coppini et al. indicated that the surface roughness did not depend on the cutting speed and increases with increasing feed rate [4]. However, this study only analyzed the surface roughness with a lower cutting speed from $10 \mathrm{~m} / \mathrm{min}$ to $30 \mathrm{~m} / \mathrm{min}$ and used the full factorial design with two levels.

Moreover, tool wear is one of the important factors to evaluate the economic and technical efficiency of the machining process. There are two main types of wear as flank and crater wear used for predicting and determining the tool life and evaluating the effect of the hard turning process. The tool wear in the machining tungsten carbide process was investigated by many research authors. The tool wear of internal turning sintered carbide using a PCD insert tool was considered by Coppini et al. [5]. The studied results indicated that neither very low cutting speeds, nor high feed rate could increase the tool life in the internal turning sintered carbide with $12 \%$ Co using the PCD inserts. The tool wear and its effect on the cutting force in the micro milling of tungsten carbide with PCD tool also were analyzed by Wu et al. [6]. The experimental results showed that the PCD tool mainly wore on the tip and the flank face. Liu et al. investigated the tool wear characteristics on the ductile cutting of tungsten carbide using CBN inserts [7]. The studied results showed that flank wear was the main type of wear in machining tungsten carbide with CBN inserts. Hence, Kim et al. compared the flank wear of a conventional bite and a chamfered bite in the turning tungsten carbide process using a diamond tool under same cutting conditions [3]. The studied results investigated that the chamfered bite had better wear resistance than the conventional bite. Okada et al. analyzed the tool wear behavior and cutting force in the cutting of tungsten carbides using a diamond coated ball end mill [8]. The study proposed the optimal cutting condition for the tungsten carbide milling process.

In this paper, we adopted the tungsten carbide turning process using the CBN insert. A full factorial model was applied for analyzing the effects of input parameters on the surface roughness and flank wear. The influences of cutting parameters on the surface roughness and the flank wear of $\mathrm{CBN}$ tool in the hard turning tungsten carbide process were analyzed by the ANOVA method.

\section{Experimental setup}

The workpieces used in this research are made by sintered tungsten carbide having a $25 \% \mathrm{wt}$ cobalt binder of the Zhuzhou Better company (YG25C). The tungsten carbide has high hardness and other special properties shown in table 1 . These workpieces having a diameter $50 \mathrm{~mm}$ and length of $80 \mathrm{~mm}$ are fixed and machined on Mazak Quick Turn Smart 200 Turning Centre (made in Japan) as shown in Figure 1. In addition, this research used the CBN inserts of DINE tool 
manufacturer (Korea). These inserts have CBN content of $65-70 \%$ and are coated by TiC layers, as table 2 .

Table 1. Properties of tungsten carbide YG25C

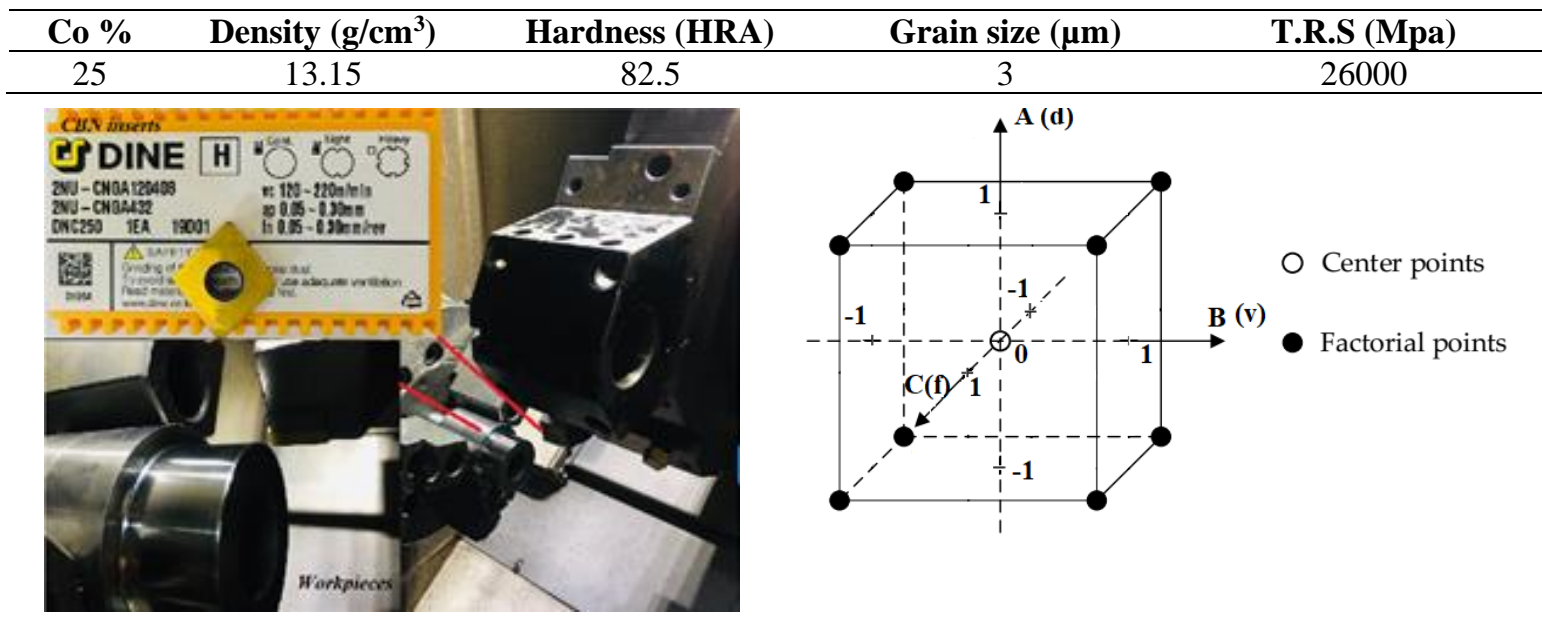

Figure 1. Experimental set up

Figure 2. $2^{k}$ model with two levels and center point

An experimental factorial model (2k) with three inputs and two-level was applied to analyze the effects of cutting parameters on surface roughness and tool wear in the machining tungsten carbide process by using Minitab 17 Software (Minitab Inc., USA). In this research, the experimental model has 8 corner points and 2 center points, as figure 2 . The value levels of the inputs were selected by basing the previous researches and shown in table 3 .

Table 2. Composition and mechanical properties of CBN inserts

\begin{tabular}{|c|c|c|c|c|c|}
\hline Coated material & CBN content $(\%)$ & Part. size $(\mu \mathrm{m})$ & \multicolumn{2}{|c|}{ Hardness (HV) } & TRS (Mpa) \\
\hline $\mathrm{TiC}$ & $65-70$ & 4 & \multicolumn{2}{|c|}{$32-34$} & $1-1.1$ \\
\hline \multicolumn{6}{|c|}{ Table 3. The cutting parameters and their levels } \\
\hline \multirow{2}{*}{\multicolumn{2}{|c|}{ Parameters }} & Units & \multicolumn{3}{|c|}{ Levels } \\
\hline & & & -1 & $\mathbf{0}$ & 1 \\
\hline \multicolumn{2}{|c|}{ Depth of cut $(d)$} & $\mathrm{mm}$ & 0.1 & 0.25 & 0.4 \\
\hline \multicolumn{2}{|c|}{ Cutting speed $(V)$} & $\mathrm{m} / \mathrm{min}$ & 30 & 50 & 70 \\
\hline \multicolumn{2}{|c|}{ Feed rate $(f)$} & $\mathrm{mm} / \mathrm{rev}$ & 0.1 & 0.15 & 0.2 \\
\hline
\end{tabular}

The measured results of the surface roughness and the flank wear are shown in table 4 . The surface roughnesswas measured by the Mitutoyo's SJ210 roughness gauge, as figure 3 .

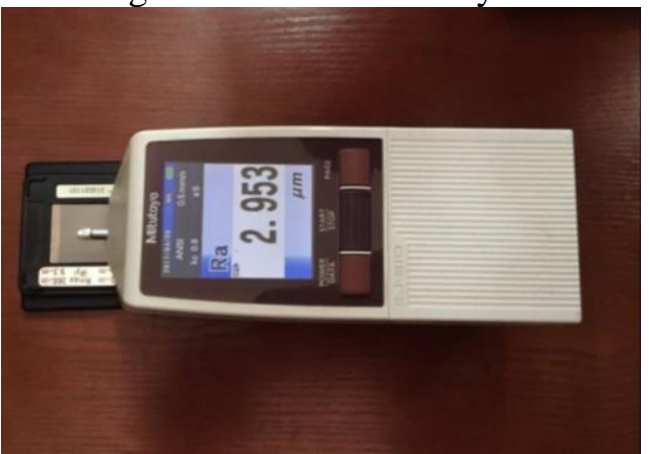

Figure 3. SJ210 roughness gauge

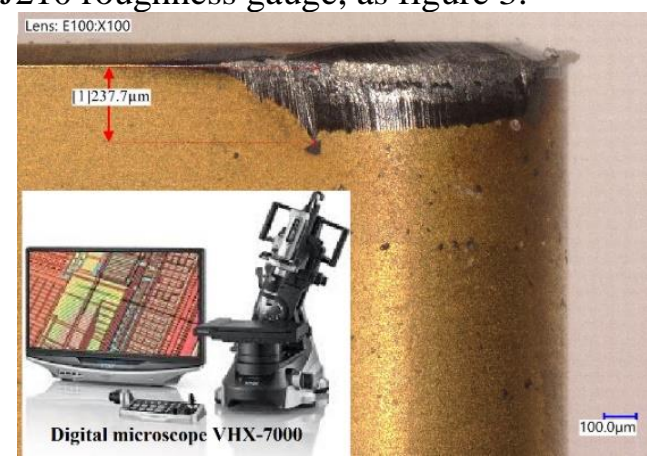

Figure 4. Flank wear measured by digital microscope VHX7000 
The flank wear width was measured by the digital microscope of Keyence Company after cutting the cutting length of $100 \mathrm{~m}$, as figure 4 .

Table 4. Experimental matric and measured results

\begin{tabular}{ccccccc}
\hline Std & Run & $\mathbf{d}(\mathbf{m m})$ & $\mathbf{V}(\mathbf{m} / \mathbf{m i n})$ & $\mathbf{f}(\mathbf{m m} / \mathbf{r e v})$ & $\mathbf{R a}(\boldsymbol{\mu m})$ & $\mathbf{V B}(\boldsymbol{\mu m})$ \\
\hline 3 & 1 & 0.1 & 70 & 0.1 & 0.224 & 307 \\
1 & 2 & 0.1 & 30 & 0.1 & 0.312 & 147.8 \\
7 & 3 & 0.1 & 70 & 0.2 & 0.424 & 350.5 \\
9 & 4 & 0.25 & 50 & 0.15 & 0.566 & 237.7 \\
6 & 5 & 0.4 & 30 & 0.2 & 1.443 & 170.5 \\
10 & 6 & 0.25 & 50 & 0.15 & 0.551 & 235 \\
4 & 7 & 0.4 & 70 & 0.1 & 0.424 & 350.5 \\
2 & 8 & 0.4 & 30 & 0.1 & 0.363 & 181.9 \\
8 & 9 & 0.4 & 70 & 0.2 & 2.210 & 355.9 \\
5 & 10 & 0.1 & 30 & 0.2 & 1.361 & 163.4 \\
\hline
\end{tabular}

\section{Result and discussion}

\subsection{Analysis of the effect of the cutting parameters on the surface roughness}

The analysis of variance (ANOVA) for the surface roughness was applied with a meaningful level of 0.05 . The results of ANOVA analysis are shown in table 5. The analysis results show that all factors and interactions between them were significantly affected by the surface roughness in the hard turning tungsten carbide process. The feed rate was the most powerful effect on surface roughness. This conclusion is also supported by $F$ statistics (descending order). However, based on the P-value, both depth of cut and cutting speed were also statistically significant to the confidence interval of $95 \%$ for surface roughness parameters. The results of ANOVA analysis also showed the need to investigate and use the curve model to describe the effect of the cutting parameters on the surface roughness.

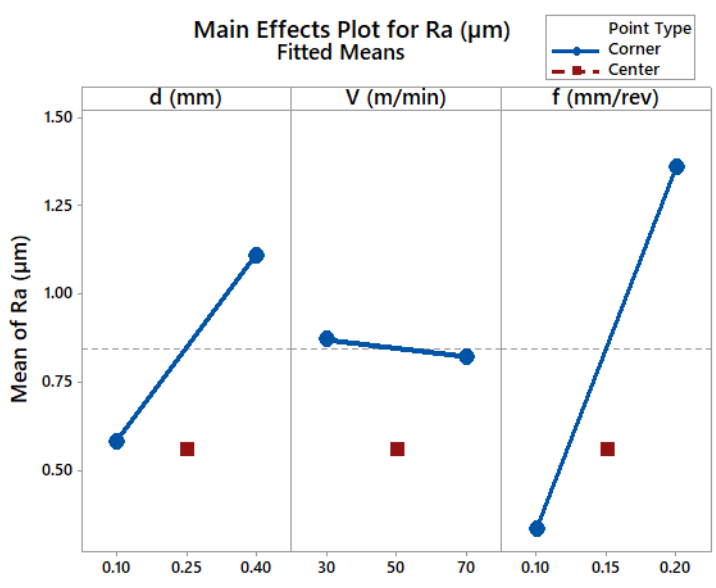

Figure 5. The main effects plot for the surface roughness

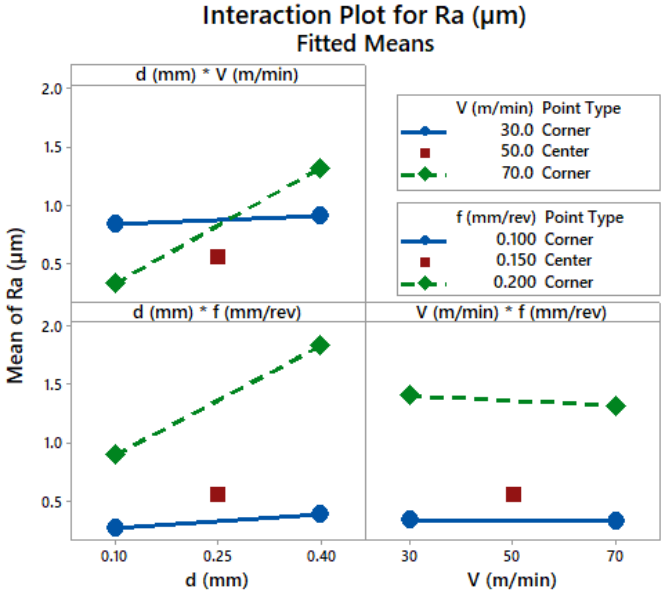

Figure 6. The interaction effect of the cutting parameter to the surface roughness

Figure 5 shows the main effects of the input parameters on the surface roughness. The result shows that the increasing cutting speed had a decreasing effect on the roughness parameters. In addition, the effect of feed rate and depth of cut change was more prominent than the cutting speed change.

The interacted effects of the cutting parameters on the surface roughness are described in Figure 6 . The interactions $\mathrm{d} * \mathrm{v}$ and $\mathrm{d} * \mathrm{f}$ affected powerfully the surface roughness. With the larger feed rate $(0.2 \mathrm{~mm} / \mathrm{rev})$, the surface roughness almost fast increased with the cutting depth from 
$0.1 \mathrm{~mm}$ to $0.4 \mathrm{~mm}$. Similarly, the cutting depth affected powerfully the surface roughness when machining at a higher cutting speed of $70 \mathrm{~m} / \mathrm{min}$ but weakly affected to the surface roughness when turning at the lower cutting speed of $30 \mathrm{~m} / \mathrm{min}$.

Table 5. Analysis of Variance for roughness surface

\begin{tabular}{lrrrrr}
\hline Source & DF & Adj SS & Adj MS & F-Value & P-Value \\
\hline Model & 8 & 3.87580 & 0.48448 & 4121.25 & 0.012 \\
Linear & 3 & 2.68299 & 0.89433 & 7607.72 & 0.008 \\
d $(\mathrm{mm})$ & 1 & 0.56109 & 0.56109 & 4773.01 & 0.009 \\
V $(\mathrm{m} / \mathrm{min})$ & 1 & 0.00490 & 0.00490 & 41.69 & 0.098 \\
$\mathrm{f}(\mathrm{mm} / \mathrm{rev})$ & 1 & 2.11700 & 2.11700 & 18008.47 & 0.005 \\
2-Way Interactions & 3 & 0.75943 & 0.25314 & 2153.40 & 0.016 \\
d (mm)*V (m/min) & 1 & 0.42936 & 0.42936 & 3652.36 & 0.011 \\
d (mm)*f $(\mathrm{mm} / \mathrm{rev})$ & 1 & 0.32751 & 0.32751 & 2786.00 & 0.012 \\
V $(\mathrm{m} / \mathrm{min}) * \mathrm{~mm} / \mathrm{rev})$ & 1 & 0.00257 & 0.00257 & 21.85 & 0.134 \\
3-Way Interactions & 1 & 0.30212 & 0.30212 & 2570.05 & 0.013 \\
d (mm)*V (m/min)*f(mm/rev) & 1 & 0.30212 & 0.30212 & 2570.05 & 0.013 \\
Curvature & 1 & 0.13126 & 0.13126 & 1116.54 & 0.019 \\
Error & 1 & 0.00012 & 0.00012 & & \\
Total & 9 & 3.87592 & & & \\
\hline
\end{tabular}

\subsection{Analysis of the effects of the cutting parameters to the flank wear}

The flank wear of the turning inserts was measured after machining with a cutting length of $100 \mathrm{~m}$ on a digital microscope. The ANOVA analysis for flank wear was determined with a mean of 0.05 . The results of the analysis of variance for the flank wear are shown in table 6 . The cutting speed and depth of cut had P-value $<0.05$, which means a significant effect on the flank wear in the turning tungsten carbide process using CBN inserts.

The results of ANOVA analysis also showed that the investigating curve model was required to describe the effect of the cutting parameters on the tool wear in the turning tungsten carbide using $\mathrm{CBN}$ insert.

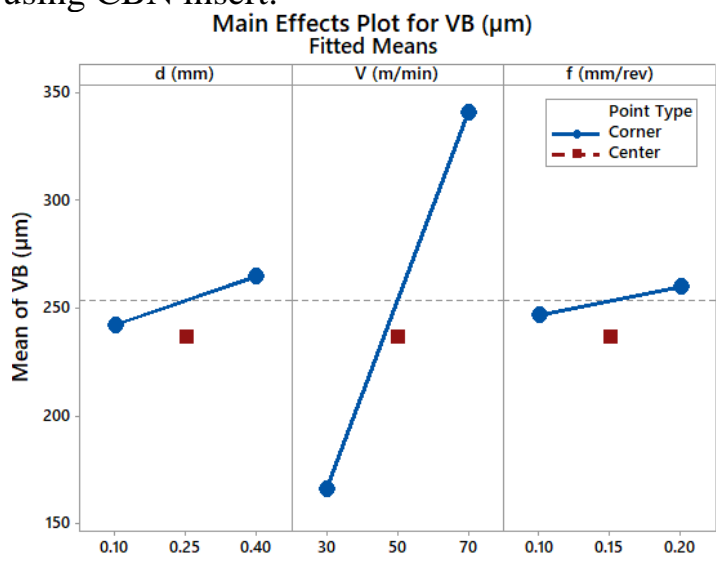

Figure 7. The main effects of the cutting parameters to the flank wear



Figure 8. The interaction effects of the cutting parameters to the flank wear

Figure 7 describes the effects of the cutting parameters on the flank wear in the hard turning of the tungsten carbide using CBN inserts. This is noticeable that the cutting speed was the most influential factor on the flank wear. Depth of cut and feed rate influenced very little to the flank wear. 
The interacted effects between the cutting parameters to the flank wear were shown in figure 8 . The results indicated that the interaction of $\mathrm{D} * \mathrm{~F}$ was weakly influenced by the flank wear.

Table 6. Analysis of Variance for flank wear

\begin{tabular}{cccccc}
\hline Source & DF & Adj SS & Adj MS & F-Value & P-Value \\
\hline Model & 8 & 63939.2 & 7992.4 & 2192.70 & 0.017 \\
Linear & 3 & 62669.7 & 20889.9 & 5731.11 & 0.010 \\
$\mathrm{~d}(\mathrm{~mm})$ & 1 & 1014.8 & 1014.8 & 278.40 & 0.038 \\
$\mathrm{~V}(\mathrm{~m} / \mathrm{min})$ & 1 & 61302.5 & 61302.5 & 16818.25 & 0.005 \\
$\mathrm{f}(\mathrm{mm} / \mathrm{rev})$ & 1 & 352.5 & 352.5 & 96.69 & 0.065 \\
2-Way Interactions & 3 & 786.9 & 262.3 & 71.96 & 0.086 \\
$\mathrm{~d}(\mathrm{~mm}) * \mathrm{~V}(\mathrm{~m} / \mathrm{min})$ & 1 & 7.4 & 7.4 & 2.03 & 0.389 \\
$\mathrm{~d}(\mathrm{~mm}) * \mathrm{f}(\mathrm{mm} / \mathrm{rev})$ & 1 & 529.8 & 529.8 & 145.34 & 0.053 \\
$\mathrm{~V}(\mathrm{~m} / \mathrm{min}) * \mathrm{f}(\mathrm{mm} / \mathrm{rev})$ & 1 & 249.8 & 249.8 & 68.52 & 0.077 \\
3-Way Interactions & 1 & 15.4 & 15.4 & 4.23 & 0.288 \\
$\mathrm{~d}(\mathrm{~mm}) * \mathrm{~V}(\mathrm{~m} / \mathrm{min}) * \mathrm{f}(\mathrm{mm} / \mathrm{rev})$ & 1 & 15.4 & 15.4 & 4.23 & 0.288 \\
Curvature & 1 & 467.2 & 467.2 & 128.17 & 0.056 \\
Error & 1 & 3.6 & 3.6 & & \\
Total & 9 & 63942.9 & & & \\
\hline
\end{tabular}

\section{Conclusion}

The effects of cutting parameters on the surface roughness and the flank wear in the hard turning process of sintered tungsten carbide WC $25 \%$ Co (82.5 HRA) using CBN inserts were analyzed by using the full factorial design. The feed rate was the most powerful factor affecting the surface roughness. In the turning tungsten carbide process, the surface roughness increase with increasing the feed rate from 0.1 to $0.2 \mathrm{~mm} / \mathrm{rev}$. Moreover, the cutting speed strongly affected the flank wear in the hard turning tungsten carbide using high CBN inserts. The results also indicated that the linear model was not suitable for describing the effect of the cutting parameters on the surface roughness and tool wear in the hard turning tungsten carbide process using CBN inserts. A response Surface Methodology design should be applied for determining the curve model to describe these effects.

\section{Acknowledgements}

The study had the support of Vietnam Ministry of Education and Training and TNU University of Technology with the project number of B2019-TNA-01.

\section{REFERENCES}

[1] M. P. Jahan, M. Rahman, and Y. S. Wong, "A review on the conventional and micro-electrodischarge machining of tungsten carbide," International Journal of Machine Tools and Manufacture, vol. 51, no. 12, pp. 837-858, 2011, doi: 10.1016/j.ijmachtools.2011.08.016.

[2] S. B. Hosseini, U. Klement, Y. Yao, and K. Ryttberg, "Formation mechanisms of white layers induced by hard turning of AISI 52100 steel," Acta Materialia, vol. 89, pp. 258-267, 2015, doi: 10.1016/j.actamat.2015.01.075.

[3] M. J. Kim, J. K. Lee, Y. Hwang, D. H. Cha, H. J. Kim, and J. H. Kim, "Experimental study of the diamond turning characteristics of tungsten carbide (Co $0.5 \%$ ) when using a chamfered diamond bite," Journal of the Korean Physical Society, vol. 61, no. 9, pp. 1390-1394, 2012, doi: $10.3938 / \mathrm{jkps} .61 .1390$.

[4] N. L. Coppini, A. E. Diniz, M. Bonandi, E. M. De Souza, and E. A. Baptista, "Hard turning of sintered cemented carbide parts: A shop floor experience," Procedia CIRP, vol. 8, pp. 368-373, 2013, doi: 10.1016/j.procir.2013.06.118. 
[5] N. L. Coppini, A. E. Diniz, F. S. Lacerda, M. Bonandi, and E. A. Baptista, "Internal turning of sintered carbide parts: tool wear and surface roughness evaluation," Journal of the Brazilian Society of Mechanical Sciences and Engineering, vol. 40, no. 4, pp. 1-7, 2018, doi: 10.1007/s40430-018-1139-z.

[6] X. Wu, L. Li, N. He, G. Zhao, F. Jiang, and J. Shen, "Study on the tool wear and its effect of PCD tool in micro milling of tungsten carbide" International Journal of Refractory Metals and Hard Materials, vol. 77, pp. 61-67, 2018, doi: 10.1016/j.ijrmhm.2018.07.010

[7] K. Liu, X. P. Li, M. Rahman, and X. D. Liu, "CBN tool wear in ductile cutting of tungsten carbide," Wear, vol. 255, no. 7-12, pp. 1344-1351, 2003, doi: 10.1016/S0043-1648(03)00061-9.

[8] M. Okada, A. Yoshida, T. Furumoto, H. Watanabe, N. Asakawa, and M. Otsu, "Mechanisms and characteristics of direct cutting of tungsten carbide using a diamond-coated carbide end mill," International Journal of Advanced Manufacturing Technology, vol. 86, no. 5-8, pp. 1827-1839, 2016, doi: 10.1007/s00170-015-8324-3. 